\title{
Innovation with Lagoon Sediments for Soil Conservation and Sustainable Intensification in the Ecuadorian Andes ${ }^{\dagger}$
}

\author{
Alexander Tituaña ${ }^{1, *}$, Marco Heredia-R. ${ }^{2,3}{ }^{\mathbb{D}}$, Bolier Torres ${ }^{4} \mathbb{D}$, Luis Valencia 5 , Jorge Vanegas ${ }^{6,7}$, \\ Otilia Vanessa Cordero-Ahiman ${ }^{6}$, Theofilos Toulkeridis ${ }^{3,8}{ }^{(D}$, Diego Puerres ${ }^{1}$, Carlos G. H. Diaz-Ambrona ${ }^{2}$ (D) \\ and Jhenny Cayambe ${ }^{1}$ (D)
}

1 School of Agricultural and Environmental Sciences, Pontificia Universidad Católica del Ecuador Sede Ibarra (PUCESI), Ibarra 100112, Imbabura, Ecuador; dmpuerres@pucesi.edu.ec (D.P.); jmcayambe@pucesi.edu.ec (J.C.)

2 AgSystems, Ceigram, itdUPM, Centro de Innovación en Tecnología para el Desarrollo, Universidad Politécnica de Madrid (UPM), 28040 Madrid, Spain; mageher@gmail.com (M.H.-R.); carlosgregorio.hernandez@upm.es (C.G.H.D.-A.)

3 Facultad de Ciencias Agropecuarias, Universidad Técnica Estatal de Quevedo (UTEQ), Quevedo Av. 7 Quito km. 1 1/2 vía a Santo Domingo de los Tsáchilas, Quevedo 120550, Los Ríos, Ecuador; ttoulkeridis@espe.edu.ec

4 Departamento de Ciencias de la Vida, Universidad Estatal Amazónica (UEA), Puyo 160101, Pastaza, Ecuador; btorres@uea.edu.ec

5 Gobierno Autónomo Descentralizado de Montúfar, Bolívar 040550, Carchi, Ecuador; lg_valenciaobando@hotmail.com

6 Group of Animal Production and Industrialization (PROANIN), Faculty of Engineering, National University of Chimborazo, Riobamba 060103, Ecuador; jl.vanegas.ruiz@gmail.com (J.V.); otilia.cordero@ucuenca.edu (O.V.C.-A.)

check for updates

Citation: Tituaña, A.; Heredia-R., M.; Torres, B.; Valencia, L.; Vanegas, J.; Cordero-Ahiman, O.V.; Toulkeridis, T.; Puerres, D.; Diaz-Ambrona, C.G.H.; Cayambe, J. Innovation with Lagoon Sediments for Soil Conservation and Sustainable Intensification in the Ecuadorian Andes. Biol. Life Sci. Forum 2021, 3, 9. https://doi.org/ 10.3390/IECAG2021-10026

Academic Editor: Youssef Rouphael

Published: 11 May 2021

Publisher's Note: MDPI stays neutral with regard to jurisdictional claims in published maps and institutional affiliations.

Copyright: (c) 2021 by the authors. Licensee MDPI, Basel, Switzerland. This article is an open access article distributed under the terms and conditions of the Creative Commons Attribution (CC BY) license (https:/ / creativecommons.org/licenses/by/ $4.0 /)$.
7 Grupo de Producción Animal e Industrialización (PROANIN), Facultad de Ingeniería, Universidad Nacional de Chimborazo, Riobamba 060103, Ecuador

8 Departamento de Ciencias de la Tierra y Construcción, Universidad de las Fuerzas Armadas ESPE, Sangolquí 171103, Ecuador

* Correspondence: eatituania@pucesi.edu.ec

+ Presented at the 1st International Electronic Conference on Agronomy, 3-17 May 2021; Available online: https: / /iecag2021.sciforum.net/.

Abstract: Agricultural production outlines the constant antagonism between the quest to achieve the highest yields and the need to preserve the physical/chemical properties of soils. The constantly increasing global demand for food prompts producers to apply more agrochemicals in order to increase their production, generating soil degradation, which is a costly and complex issue to solve. Based on this context, we targeted a variety of objectives such as (a) to evaluate the effectiveness of lagoon sediments in soil recovery; (b) to analyze the effect of sediment on the yield of the coriander crop; and (c) to determine soil reclamation costs. The experiment was developed in the province of Imbabura, located in northern Ecuador. For this, we occupied a surface area per plot of $3 \mathrm{~m}^{2}$ and used a completely randomized block experimental design. Four doses of sediment were applied, being mixed with soil. The benefits of the use of lagoon sediments are evidenced in the nutritional quality of the soil after its application, determined by the physical and chemical analysis that reveals an increase of $3.9 \mathrm{ppm}$ of the initial $\mathrm{N}$, even after vegetative consumption. Similarly, the best electric conductivity (E.C) was $0.85 \mathrm{mS} / \mathrm{cm}$, which promoted a higher crop yield compared to the control treatment, becoming an innovative alternative for soil recovery. This activity allowed reconciliation of the intensive agriculture with soil conservation.

Keywords: lagoon sediments; soil conservation; intensification; sustainability

\section{Introduction}

The inadequate management of the soil as a direct consequence of anthropic use results in its deterioration, based on the responsibility of agriculture, forestry and livestock [1]. 
Due to the use of agrochemicals, the excessive use of agricultural machinery, the empirical application of synthetic fertilizers, and above all, the agronomic ignorance of the crops, cause constant physical, chemical and microbiological degradation in the soil. In Ecuador, it constitutes the greatest environmental problem, since $48 \%$ of the surface of the national territory presents soil erosion [2]. The cause of this reality is that several crops, including coriander, due to its constant, rapid and high consumption of nutrients from the soil, is considered a deterioration of the soil, making it ideal for current research [3].

Therefore, the use of lacustrine material from the Colta lagoon in the province of Chimborazo is proposed as an alternative organic fertilizer, which does not act negatively on the rhizosphere and allows agro-environmentally clean agriculture to be sustained. Through the agro-industrial processes to which the sediment is subjected, heavy metals and pathogens are eliminated, allowing their application in deteriorated soils. This enables the improvement of nutritional quality and soil structure, and the promotion of sustainable agriculture [4].

\section{Materials and Methods}

The present research was conducted in the La Victoria sector of the city of Ibarra, in northern Ecuador, at $2100 \mathrm{~m}$ above sea level, in a sandy loam type soil and a predominantly semi-deciduous forest, within a shrub ecosystem in the north of the valleys (Figure 1).
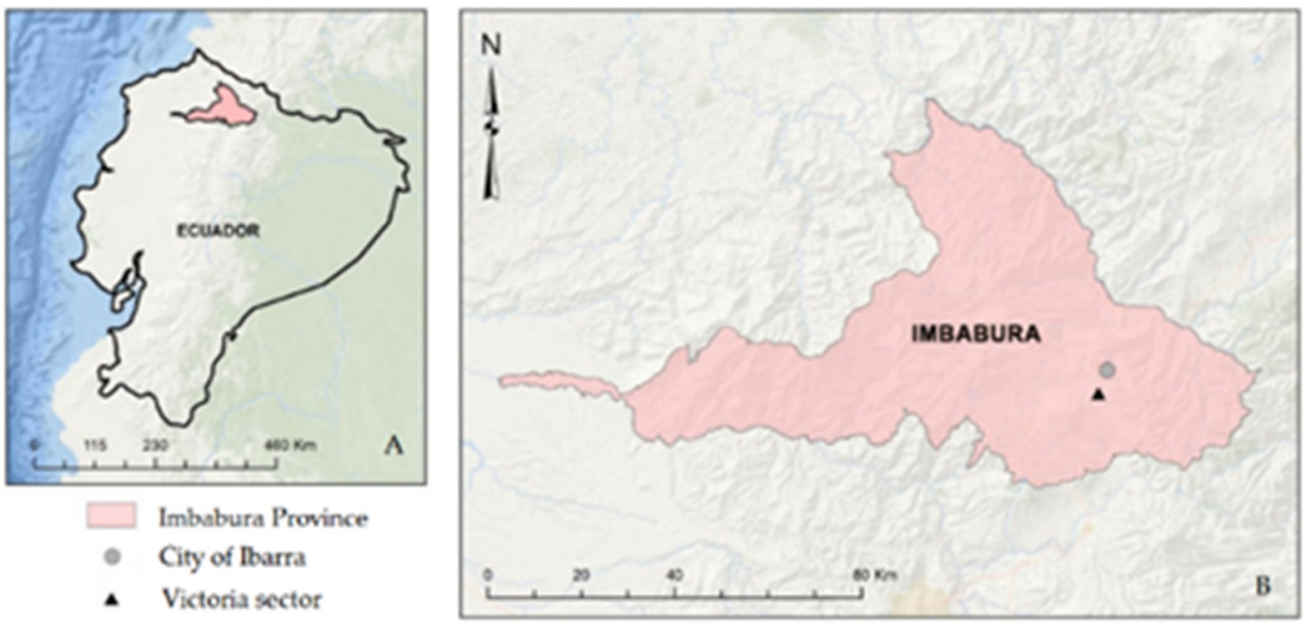

Figure 1. (A) position of Ecuador and within the Province of Imbabura, and (B) the La Victoria sector and the city of Ibarra within the Province.

The condition of the soil was determined through the initial physical-chemical analysis of the soil, in order to determine macro and micro nutrients, organic matter, electrical conductivity and soil $\mathrm{pH}$. The samples were taken in a diagonal pattern in relation to the study area [5]. The study factor of the research is the compost (fertilizer), based on dredged sediments from the Colta lagoon, which were applied in five different treatments (Table 1).

Table 1. Percentage of treatments applied during the current study.

\begin{tabular}{ccc}
\hline Code & Compost (\%) & Characteristics \\
\hline T1 & 100 & $100 \%$ of the compost and $0 \%$ of the soil \\
T2 & 75 & $75 \%$ of the compost and $25 \%$ of the soil \\
T3 & 50 & $50 \%$ of the compost and $50 \%$ of the soil \\
T4 & 25 & $25 \%$ of the compost and $75 \%$ of the soil \\
T5 & 0 & $0 \%$ of the compost and $100 \%$ of the soil (core) \\
\hline
\end{tabular}

The most adequate dosage of compost in the crops promotes the ideal development of the crop. Therefore, based on the recommendation to apply $50 \%$ of fertilizer to crops 
suggested by [6], this amount is considered, along with the alternative of administering doses with $25 \%$ less than the starting point, as well as doses with $75 \%$ and $100 \%$ fertilizer.

The research is based on the statistical model of completely random block design (CRBD), consisting of 15 experimental units distributed in four treatments with a control, and three repetitions of each treatment. Each experimental unit presented an area of $3.00 \mathrm{~m}^{2}$ with $3 \mathrm{~m}$ in length and $1 \mathrm{~m}$ in width.

\section{Evaluation of Phenological Variables}

Days to germination and days to harvest: This variable was determined based on the visualization of emerging plants, from their sowing, until the moment when $90 \%$ of germinated plants are observed in each experimental unit [7]. On the other hand, the days to harvest were established based on the recommended phenological characteristics, such as leaves with intense green coloration and an average height of $0.44 \mathrm{~m}$ [8-10].

Stem height: In order to determine this variable, a vernier and a tape measure were required, which allows the measurement from the root neck to the end of the main stem. Hereby, data collection was conducted from day 20 of the crop every 10 days, until 70 days. The choice of plants to be registered was chosen by means of the elimination criterion by edge effect [8].

Crop yield: This variable was determined by means of an analytical balance in which the mass of each experimental unit was recorded, to later determine the number of bundles for each unit, and finally extrapolate them to a production per hectare [9].

Soil evaluation: In order to determine the quality and state of the soil, the pre-sowing physical-chemical analyses were compared with the post-harvest soil analyses. This allowed observation of the effects of the fertilizer at the beginning and at the end of the investigation [11].

Economic analysis: Based on the International Corn and Wheat Center (CIMMYT) [12], the economic analysis was performed, considering the cost of inputs [3], in order to determine the cost of soil recovery with each treatment.

\section{Results and Discussion}

\subsection{Days to Germination and Days to Harvest}

The percentage of compost present in treatment T4 (25\% compost and $75 \%$ soil), and treatment T1 (100\% compost and 0\% soil), allowed the seeds to germinate in 11 days (on average) (Table 2). This reaffirmed that the use of sediments promotes a prompt emergence thanks to the structural improvement of the soil required in this stage [6,13]. Similarly, the sediment as compost allowed the harvest time to improve (57 days avg.) with the T3 treatment (50\% compost and $50 \%$ soil), due to the nutritional value provided by the compost $[8,10]$ (Table 3).

Table 2. Average days of germination and Tukey test at $5 \%$.

\begin{tabular}{cccc}
\hline Code & Compost (\%) & Average (Days) & Range \\
\hline T4 & 25 & 11 & $\mathrm{~A}$ \\
T1 & 100 & 11 & $\mathrm{~A}$ \\
T5 & 0 & 13 & $\mathrm{AB}$ \\
T2 & 75 & 13 & $\mathrm{AB}$ \\
T3 & 50 & 15 & $\mathrm{~B}$ \\
\hline
\end{tabular}

\subsection{Stem Height}

The results obtained by the T3 treatments (50\% compost and 50\% soil) reflect the highest height obtained at 70 days, with $51.47 \mathrm{~cm}$ (avg.), exceeding its average height $[9,10]$ (Table 4). This is in agreement that the addition of $50 \%$ sediment-based compost promotes growth, thanks to the provision of nutrients for the plant in the development stage $[6,11]$. 
Table 3. Average days to harvest and 5\% Tukey test.

\begin{tabular}{cccc}
\hline Code & Compost (\%) & Average (Days) & Range \\
\hline T3 & 50 & 57 & $\mathrm{~A}$ \\
T4 & 25 & 62 & $\mathrm{AB}$ \\
T2 & 75 & 71 & $\mathrm{~B}$ \\
T5 & 0 & 73 & $\mathrm{BC}$ \\
T1 & 100 & 76 & $\mathrm{C}$ \\
\hline
\end{tabular}

Table 4. Average stem height and Tukey's test at 5\%.

\begin{tabular}{|c|c|c|c|c|c|c|c|c|}
\hline \multirow[b]{2}{*}{ Code } & \multirow{2}{*}{$\begin{array}{c}\text { Compost } \\
(\%)\end{array}$} & \multicolumn{6}{|c|}{ Height } & \multirow[b]{2}{*}{ Range } \\
\hline & & $\begin{array}{c}\text { Day } 20 \\
(\mathrm{~cm})\end{array}$ & $\begin{array}{c}\text { Day } 30 \\
(\mathrm{~cm})\end{array}$ & $\begin{array}{c}\text { Day } 40 \\
(\mathrm{~cm})\end{array}$ & $\begin{array}{c}\text { Day } 50 \\
(\mathrm{~cm})\end{array}$ & $\begin{array}{c}\text { Day } 60 \\
(\mathrm{~cm})\end{array}$ & $\begin{array}{c}\text { Day } 70 \\
(\mathrm{~cm})\end{array}$ & \\
\hline T3 & 50 & 7.70 & 8.66 & 19.12 & 32.51 & 46.79 & 51.47 & A \\
\hline $\mathrm{T} 4$ & 25 & 9.05 & 10.06 & 16.95 & 28.81 & 43.21 & 47.53 & $\mathrm{AB}$ \\
\hline $\mathrm{T} 2$ & 75 & 7.09 & 7.85 & 15.24 & 25.90 & 38.86 & 42.75 & $\mathrm{AB}$ \\
\hline T5 & 0 & 6.70 & 7.40 & 13.92 & 23.67 & 35.50 & 39.05 & B \\
\hline $\mathrm{T} 1$ & 100 & 7.00 & 7.70 & 14.06 & 23.90 & 33.99 & 37.39 & B \\
\hline
\end{tabular}

\subsection{Yield}

In Table 5, it was observed that the T3 treatment ( $50 \%$ of compost and $50 \%$ of soil), was characterized as the best, since it reached $156.94 \mathrm{~g}$ per plant (avg.), which, when extrapolating towards a production in 1 ha with 200,000 plants, the average and adjusted yield are of about $31,388 \mathrm{~kg} \mathrm{ha}^{-1}$ and $23,541 \mathrm{~kg} \mathrm{ha}^{-1}$, respectively. This allows 79,800 bundles of $295 \mathrm{~g}$ each to be obtained in a production equivalent to $1 \mathrm{ha}$. Coinciding with the sediment-based compost, due to its nutritional load [14] and structural improvement in the soil, it concedes the best development of the plants [15], increasing their yield [16,17].

Table 5. Average yield and Tukey test at 5\%.

\begin{tabular}{cccc}
\hline Code & Compost (\%) & Average Yield (g Plant $\left.{ }^{-1}\right)$ & Range \\
\hline T3 & 50 & 156.94 & $\mathrm{~A}$ \\
T4 & 25 & 145.12 & $\mathrm{AB}$ \\
T2 & 75 & 130.28 & $\mathrm{~B}$ \\
T1 & 100 & 113.73 & $\mathrm{BC}$ \\
T5 & 0 & 96.25 & $\mathrm{C}$ \\
\hline
\end{tabular}

\subsection{Soil Evaluation}

Treatment T1 (100\% compost and $0 \%$ soil) presented the best results, as it demonstrated less nutritional wear after harvest. Treatments T2 (75\% compost and 25\% soil), T3 (50\% compost and $50 \%$ soil) and T4 (25\% compost and $75 \%$ soil), similarly presented good results, with wear balanced nutritional at the end of the study (Tables 6 and 7). Nutritional stability and positive structural modification were verified [15], stabilizing the sandy loam soil to loamy soil [18], allowing greater retention of moisture and oxygenation of the soil [11,19], balancing the EC at $0.85 \mathrm{mS} \mathrm{cm}^{-1}$ [20], and also at the end of the study.

Table 6. Physical-chemical analysis of the soil prior to sowing.

\begin{tabular}{|c|c|c|c|c|c|c|c|c|c|c|c|c|c|c|}
\hline \multirow{2}{*}{ Code } & $\mathbf{N}$ & $\mathbf{P}$ & K & $\mathrm{Ca}$ & $\mathrm{Mg}$ & $S$ & $\mathrm{Fe}$ & B & $\mathrm{Zn}$ & $\mathrm{Cu}$ & Mn & \multirow{2}{*}{ E.C. ${ }^{1} \mathrm{mS} \mathrm{cm} \mathrm{cm}^{-1}$} & \multirow{2}{*}{$\mathrm{pH}$} & \multirow{2}{*}{ M.O. (\%) } \\
\hline & \multicolumn{2}{|c|}{$\left(\mathrm{mg} \mathrm{kg}^{-1}\right)$} & \multicolumn{3}{|c|}{$\left(\right.$ meq $\left.100 \mathrm{~mL}^{-1}\right)$} & \multicolumn{6}{|c|}{$\left(\mathrm{mg} \mathrm{kg}^{-1}\right)$} & & & \\
\hline T1 & 57.92 & 28.2 & 1.64 & 60.58 & 7.83 & 132.67 & 155.28 & 0.35 & 2.86 & 13.57 & 31.51 & 1.61 & 7.42 & 7.43 \\
\hline T2 & 70.15 & 32.3 & 1.21 & 49.19 & 6.95 & 119.22 & 105.51 & 0.25 & 3.7 & 8.62 & 26.32 & 1 & 7.45 & 5.98 \\
\hline T3 & 23.41 & 32.24 & 1.09 & 46.68 & 7.19 & 79.8 & 103.08 & 0.31 & 3.68 & 7.06 & 15.56 & 1.15 & 7.48 & 5.54 \\
\hline $\mathrm{T} 4$ & 14.71 & 46.97 & 0.87 & 41.76 & 5.97 & 40.13 & 135.82 & 0.33 & 12.6 & 10.23 & 41.41 & 0.92 & 7.34 & 3.19 \\
\hline T5 & 48.06 & 43.28 & 0.66 & 41.23 & 5.25 & 19.16 & 121.79 & 0.85 & 3.86 & 11.83 & 27.04 & 0.44 & 7.22 & 2.53 \\
\hline
\end{tabular}

${ }^{1}$ Electric conductivity (E.C.) $=$ Ability of the soil to conduct electrical current and take advantage of salts through this conduction [20]. 
Table 7. Post-harvest soil physical-chemical analysis.

\begin{tabular}{|c|c|c|c|c|c|c|c|c|c|c|c|c|c|c|}
\hline \multirow{2}{*}{ Code } & $\mathbf{N}$ & $\mathbf{P}$ & $K$ & $\mathrm{Ca}$ & $\mathrm{Mg}$ & $S$ & $\mathrm{Fe}$ & B & $\mathrm{Zn}$ & $\mathrm{Cu}$ & Mn & \multirow{2}{*}{ E.C. $\mathrm{mS} \mathrm{cm}^{-1}$} & \multirow{2}{*}{$\mathrm{pH}$} & \multirow{2}{*}{ M.O. (\%) } \\
\hline & \multicolumn{2}{|c|}{$\left(\mathrm{mg} \mathrm{kg}^{-1}\right)$} & \multicolumn{3}{|c|}{$\left(\right.$ meq $\left.100 \mathrm{~mL}^{-1}\right)$} & \multicolumn{6}{|c|}{$\left(\mathrm{mg} \mathrm{kg}^{-1}\right)$} & & & \\
\hline $\mathrm{T} 1$ & 37.3 & 35.27 & 0.83 & 17.3 & 6.1 & 42.65 & 163.51 & 0.25 & 2.61 & 7.93 & 38.0 & 0.75 & 7.43 & 6.97 \\
\hline T2 & 34.7 & 42.03 & 0.83 & 15.9 & 5.66 & 22.03 & 117.07 & 0.34 & 5.45 & 9.67 & 35.3 & 0.71 & 7.39 & 5.07 \\
\hline T3 & 27.3 & 47.81 & 0.8 & 12.9 & 5.81 & 12.79 & 155.58 & 0.26 & 6.97 & 10.7 & 29.2 & 0.85 & 7.32 & 3.83 \\
\hline $\mathrm{T} 4$ & 41 & 58.1 & 0.72 & 11.4 & 5.05 & 27.48 & 173.8 & 0.25 & 5.31 & 7.53 & 39 & 0.74 & 7.3 & 3.77 \\
\hline T5 & 26 & 35.43 & 0.59 & 8.43 & 3.81 & 9.71 & 166.18 & 0.41 & 4.92 & 7.85 & 31.7 & 0.38 & 7.17 & 2.05 \\
\hline
\end{tabular}

\subsection{Economic Analysis}

The benefit/cost ratio has an index greater than one $\left(\mathrm{B} \mathrm{C}^{-1}>1\right)$, in each of the results. On the other hand, treatment T4 (25\% compost and $75 \%$ soil) presented higher profitability, with a value of $\$ 3.38$, which reflects that for each monetary unit that is invested, the investment is recovered and a profit of $\$ 2.38$ is realized (Table 8). However, the T3 treatment at the end of the study adheres to the main objective of the research, improving the characteristics of the soil and production. Therefore, it would be considered the best treatment at the end of the study.

Table 8. Economic analysis of the research.

\begin{tabular}{|c|c|c|c|c|c|}
\hline & \multicolumn{5}{|c|}{ Code } \\
\hline & T1 & T2 & T3 & $\mathrm{T} 4$ & T5 \\
\hline Average yield $\left(\mathrm{kg} \mathrm{ha}^{-1}\right)$ & 22,746 & 26,056 & 31,388 & 29,024 & 23,890 \\
\hline Adjusted yield $\left(\mathrm{kg} \mathrm{ha}^{-1}\right)$ & $17,059.5$ & 19,542 & 23,541 & 21,768 & $14,437.5$ \\
\hline Price ( $\$$ stranded of $295 \mathrm{~g}^{-1}$ ) & 0.25 & 0.25 & 0.25 & 0.25 & 0.25 \\
\hline Gross profit from the field (S ha ${ }^{-1}$ ) & $14,457.2$ & 16,561 & 19,950 & $18,447.46$ & $12,235.1$ \\
\hline Compost cost $(\$ /$ ha / ciclo $)$ & 6388.67 & 4791.89 & 3192.00 & 1596.78 & 0 \\
\hline Production cost $\left(\$ \mathrm{ha}^{-1}\right)$ & 3866.63 & 3866.63 & 3866.63 & 3866.63 & 3866.63 \\
\hline Net profit $\left(\$ \mathrm{ha}^{-1}\right)$ & 4201.90 & 7902.50 & $12,891.37$ & $12,984.05$ & 8368.54 \\
\hline Benefit/Cost $\left(\mathrm{B} \mathrm{C}^{-1}\right)$ & 1.41 & 1.91 & 2.83 & 3.38 & 3.16 \\
\hline
\end{tabular}

Author Contributions: Conceptualization, A.T. and J.C.; methodology, J.C., D.P. and L.V.; software, J.C.; validation, A.T., D.P., L.V. and B.T.; formal analysis, investigation, resources, data curation, writing-original draft preparation, J.C., M.H.-R., C.G.H.D.-A. and T.T.; economic analysis, J.V. and O.V.C.-A.; writing-review and editing, J.C. and T.T. All authors have read and agreed to the published version of the manuscript.

Funding: This research was funded by Pontificia Universidad Católica del Ecuador Sede Ibarra (PUCESI) as a graduate project from the School of Agricultural and Environmental Sciences and as a research grant.

Institutional Review Board Statement: Not applicable.

Informed Consent Statement: Not applicable.

Data Availability Statement: Not applicable.

Acknowledgments: The authors thank the researchers from the Central Market of the Gobierno Autónomo Descentralizado de Montúfar for their collaboration in participatory workshops.

Conflicts of Interest: The authors declare no conflict of interest.

\section{References}

1. Brissio, P.A.; Savini, M. Evaluación Preliminar del Estado de Contaminación en el Suelo de la Provincia de Neuquen Donde se Efectuaron Actividades de Explotación Hidrográfica. Bachelor's Thesis, Universidad Nacional de Comahue, Neuquén, Argentina, 2005.

2. Suquilanda, M.B. El Deterioro de los Suelos en el Ecuador y la Producción Agrícola. In XI Congreso Ecuatoriano de la Ciencia del Suelo, Quito, Ecuador, 29-31 October 2008; Universidad Central del Ecuador: Quito, Ecuador, 2008.

3. Sinaproy. Sustrato Orgánico Mineral; SINAPROY: Quito, Ecuador, 2015. 
4. Estrada, E.I.; Gracía, A.; Cardozo, I.; Gutíerrez, A.; Baena, D. Sánchez S y Vallejo, A. Cultivo de Cilantro. Variedad UNAPAL Precoso; Universidad Nacional de Colombia: Bogotá, Colombia, 2004.

5. Instituto de Investigaciones Agropecuarias (INIA). Centro de Suelos y Nutrición Vegetal. Análisis de suelo; La Pintana: Santiago de Chile, Chile, 2012; Volume 1, pp. 1-5.

6. Mendoza-Hernández, D.; Fornes, F.; Belda, R.M. Compost and vermicompost of horticultural wasted as substrates for cutting rooting and growth of rosemary. Sci. Hortic. 2014, 178, 192-202. [CrossRef]

7. Hernández, J. Crecimiento y desarrollo del Cilantro Coriandrum sativum L. por efecto del Fotoperiodo y la Temperatura y su Control con Fitoreguladores. Ph.D. Thesis, Universidad Autónoma de Nuevo Leon, San Nicolás de los Garza, Mexico, 2003.

8. Carberry, A. How to Measure Growth Rate of Plants. 2019. Available online: https://www.wikihow.com/Measure-Growth-Rateof-Plants (accessed on 3 May 2021).

9. González, E. Cilantro (Coriandrum sativum L.) un Cultivo Ancestral con Potencial Sub-Utilizado, 9th ed.; Inifap: Mexico City, Mexico, 2017.

10. Duwal, A.; Nepal, A.; Luitel, S.; Acharya, S.; Pathak, R.; Poudel, P.R.; Shrestha, J. Evaluation of coriander (Coriadrum sativum L.) varieties for growth and yield parameters. Nepal. J. Agric. Sci. 2019, 18, 36-46.

11. Ojeda, G. Aplicación en Superficie de Lodos de Depuradora y sus Recursiones Sobre la Erosión y las Propiedades Físicas del suelo. Ph.D. Thesis, Universidad Autónoma de Barcelona, Barcelona, Spain, 2005.

12. Centro Internacional de Mejoramiento de Maíz y Trigo (CIMMYT). La Formulación de Recomendaciones a Partir de Datos Agronómicos: Un Manual Metodológico de Evaluación Económica; CIMMYT: Veracruz, México, 1988.

13. Jarvis, J.C.; Moore, K.A. Effects of seed source, sediment type, and burial depth on mixed-annual and perennial Zostera marina L. seed germination and seedling establishment. Estuaries Coasts 2015, 38, 964-978. [CrossRef]

14. Avagyan, A.B. A contribution to global sustainable development: Inclusion of microalgae and their biomass in production and bio cycles. Clean Techn. Environ. Policy 2008, 10, 313-317. [CrossRef]

15. Marschner, H. Marschner's Mineral Nutrition of Higher Plantas, 3rd ed.; Academic Press: Londres, Australia, 2011.

16. Coll, J.B.; Rodrigo, G.N.; García, B.S.; Tamés, R.S. Fisiología Vegetal; Comercial Grupo ANAYA, SA: Madrid, Spain, 2019.

17. Taiz, L.; Zeiger, E. Plant Physiology, 3rd ed.; Sinauer Associates. Inc.: Sunderland, UK, 2006.

18. Departamento de Agricultura de los Estados Unidos (USDA). Claves Para la Taxonomía del Suelos. Traducido, 12th ed.; Ortiz, S., Gutiérrez, M., Eds.; USDA: Texcoco, Mexico, 2014; pp. 47-238.

19. Limón, G. Los lodos de las Plantas de Tratamiento de Aguas Residuales, "Problema o Recurso"; Academia de ingeniería México (en revisión): Mexico City, Mexico, 2013.

20. Barbaro, L.A.; Karlanian, M.; Mata, D.A. Importancia del pH y la Conductividad Eléctrica (CE) en los Sustratos Para Plantas; Instituto Nacional de Tecnología Agropecuaria (INTA): Buenos Aires, Argentina, 2014; pp. 7-9. 